BUNDA EDU-MIDWIFERY JOURNAL (BEMJ)

p-ISSN: 26227482 dan e-ISSN: 26227487

Vol. 4 No. 2 (2021)

\title{
HUBUNGAN ANTARA TINGKAT PENGETAHUAN IBU DENGAN PEMBERIAN VITAMIN A DOSIS TINGGI PADA BALITA DI PUSKESMAS SEGIRI SAMARINDA
}

\author{
Fauziah $^{1}$, Rahmawati ${ }^{2}$ \\ Akademi Kebidanan Bunga Husada ${ }^{1,2}$ \\ fauziah.fahrullah@gmail.com ${ }^{1}$, rahmawati.riadi@gmail.com ${ }^{2}$
}

\section{Kata Kunci: \\ Pengetahuan ibu, Vitamin A pada \\ Balita,}

\begin{abstract}
ABSTRAK
Vitamin A merupakan zat gizi yang essensial bagi manusia, karena zat gizi ini sangat penting dan konsumsi makanan kita cenderung belum mencukupi dan masih rendah sehingga harus dipenuhi dari luar. Pada anak balita akibat KVA (Kekurangan Vitamin A) akan meningkatkan kesakitan dan kematian, mudah terkena penyakit infeksi, seperti diare, radang paru-paru, pneumonia, dan akhirnya kematian. Penelitian ini bertujuan untuk mengetahui hubungan antara Tingkat Pengetahuan Ibu dengan Pemberian Vitamin A Dosis Tinggi pada Balita di Puskesmas Segiri tahun 2018.

Penelitian ini menggunakan metode deskriptif analitik dengan rancangan cross sectional dengan populasi ibu-ibu yang memiliki balita yang ada di Puskesmas Segiri Samarinda 2018.

Hasil penelitian menunjukkan terdapat hubungan yang signifikan pada taraf antara Tingkat Pengeahuan Ibu dengan pemberian Vitamin A Dosis Tinggi pada Balita di Puskesmas Segiri Samarinda tahun 2018.
\end{abstract}

\section{PENDAHULUAN}

Vitamin A merupakan salah satu zat gizi dari golongan vitamin yang sangat diperlukan oleh tubuh untuk menjaga Kesehatan mata (agar dapat melihat dengan baik). Selain itu juga untuk menjaga Kesehatan tubuh secara umum yaitu meningkatkan daya tahan tubuh dalam melawan penyakit misalnya campak, diare, dan penyakit infeksi lainnya (Febry K. D. \& Marendra, 2010). Diseluruh dunia diantara anak-anak prasekolah diperkirakan terdapat sebanyak 6-7 juta kasus baru xeropthalmia tiap tahun, kurang lebih $10 \%$ diantara kerusakan kornea ini $60 \%$ meninggal dalam waktu satu tahun, sedangkan diantara yang hidup $25 \%$ menjadi buta dan 50-60\% setegah buta. Diperkirakan pada waktu sebanyak 3 juta anak-anak buta karena kekurangan vitamin A pada tingkat yang lebih ringan (Almatsier, 2003). Perkiraan World Health Organization (WHO), terdapat lebih dari 7 juta orang menjadi buta setiap tahun. Saat ini diperkirakan 180 juta orang di seluruh dunia mengalami gangguan penglihatan, dari angka tersebut terdapat antara 40-45 juta menderita kebutaan dan 1 diantaranya terdapat di South East Asia (World Health Organization, 2005).

10 Juta balita di Indonesia kekurangan vitamin A (KVA) Dari jumlah target sebesar 20 juta balita pravelensia vitamin A (KVA) berdasarkan survei vitamin A tahun 2008, menunjukkan xerapthalmia sebesar $0,33 \%$, 
namun secara subklinis prevalensi KVA (kadar serum retinol dalam darah) pada balita sebesar 50\%, akibat kekurangan vitamin A akan meningkatkan mortalitas dan morbilitas, anak muda terkena penyakit infeksi seperti diare, radang paru, pneumonia dan KVA adalah buta senja dan tandatanda lain dari xeropthalmia termasuk kerusakan kornea (keratomalasia) dan kebutaan. Perbaikan status vitamin A pada anak-anak yang KVA, disertai upaya pengobatan pada semua kasus campak dengan pemberian vitamin A dapat mengurangi tingkat kegawatan dari penyakit-penyakit infeksi dimasa anak-anak, sehingga dapat meningkatkan kesempatan bagi kelangsungan hidup mereka (Yuliarti, 2016).

Berdasarkan laporan tahun 2017 presentasi balita umur 6-59 bulan yang mendapat vitamin A di Kalimantan Timur sebanyak 92,69 \% (Departemen Kesehatan Republik Indonesia, 2017). Berdasarkan laporan dari Dinas Kesehatan Kota Samarinda jumlah keseluruhan balita yang tercatat di Dinas Kesehatan Kota Samarinda sebanyak 129703 orang. Balita yang mendapatkan Vitamin A ke di Puskesmas Kota Samarinda pada usia 6-11 bulan sebanyak 14745 orang (80.79\%) dan balita yang mendapatkan Vitamin A pada usia 12-59 sebanyak 64287 orang $(57.68 \%)$ jadi keseluruhan balita yang mendapatkan Vitamin A berjumlah 79032 (70.91\%) (Dinas Kesehatan Kota Samarinda, 2017).

Berdasarkan studi pendahuluan di Puskesmas Segiri Samarinda tahun 2018 balita sebanyak 4292 orang. Diketahui bahwa jumlah keseluruhan balita yang berkunjung dalam pemberian vitamin A berjumlah 3295 orang, balita usia 6-11 bulan berjumlah 283 orang atau $85,24 \%$ dan balita 12-59 bulan berjumlah 3012 orang atau $73,75 \%$. Dengan jumlah cakupan pemberian vitamin A pada balita dari jumlah target yang diharapkan harus mendapatkan vitamin A $90 \%$.
Hasil kegiatan studi menyatakan bahwa vitamin A merupakan zat gizi yang essensial bagi manusia, karena zat gizi ini sangat penting dan konsumsi makanan kita cenderung belum mencukupi dan masih rendah sehingga harus dipenuhi dari luar. Pada anak balita akibat KVA (Kekurangan Vitamin A) akan meningkatkan kesakitan dan kematian, mudah terkena penyakit infeksi, seperti diare, radang paru-paru, pneumonia, dan akhirnya kematian.

Akibat lain yang sangat berdampak serius dari KVA adalah buta senja dan manifestassi dari xeropthalmia termasuk kerusakan kornea dan kebutaan. Vitamin A bermanfaat untuk menurunkan angka kematian dan angka kesakitan karena vitamin A dapat meningkatkan kekebalan tubuh teradapat penyakit infeksi seperti campak, diare, dan ISPA (Infeksi Saluran Pernafasan Akut). Ibu nifas yang cukup mendapatkan vitamin A akan meningkatkan kandungan vitamin A dalam ASI (Air Susu Ibu), sehingga bayi yang disusui kebal terhadap penyakit. Disamping itu kesehatan ibu lebih cepat pulih. Upaya perbaikan status Vitamin A harus mulai sedini mungkin pada masa kanak-kanak terutama anak yang menderita kekurangan vitamin A (Departemen Kesehatan Republik Indonesia, 2017).

Berdasarkan penelitian di atas maka peneliti tertarik untuk meneliti Hubungan antara Tingkat Pengetahuan Ibu dengan Pemberian Vitamin A Dosis Tinggi pada Balita di Puskesmas Segiri tahun 2018

\section{METODE}

Penelitian ini menggunakan metode deskriptif analitik dengan rancangan cros sectional .Penelitian dilakukan di wilayah kerja Puskesmas Segiri Samarinda tahun 2018, Tanggal 6-17 Juli 2018. Populasi dalam penelitian ini adalah ibu-ibu yang memiliki balita yang ada di puskesmas Segiri Samarinda 2018. menggunakan tekhnik pengambilan sampel secara Accidental sampling (Responden yang kebetulan ada 
saat penelitian dilakukan). Data akan disajikan dalam bentuk tabel. Kemudian data akan dianalisis untuk melihat hubungan antar variabel. Analisis data akan menggunakan uji analisis chi-square, menggunakan software SPSS

\section{HASIL DAN PEMBAHASAN}

Penelitian ini menggambarkan hasil beserta pembahasannya berdasarkan pada teknik pengolahan data sesuai yang telah diuraikan sebelumnya.

Berdasarkan kuesioner yang disebarkan pada seluruh responden yaitu ibu-ibu yang memiliki balita usia 6-11 bulan dan 1-5 tahun yang ada di Puskesmas Segiri Samarinda sebanyak 46 orang, maka didapatkan hasil sebagai berikut :

\section{Analisa Unvariat}

Tabel 2. Ditribusi Frekuensi Responden Berdasarkan Pemberian Vitamin A Dosis Tinggi pada Balita Periode bulan Juli 2018

\begin{tabular}{lcc}
\hline $\begin{array}{l}\text { Pemberian Vitamin } \\
\text { A Dosis Tinggi } \\
\text { pada Balita }\end{array}$ & Frekuensi & Presentase \\
\hline $\begin{array}{l}\text { Diberikan Vitamin } \\
\text { A }\end{array}$ & 34 & $74 \%$ \\
$\begin{array}{l}\text { Tidak Diberikan } \\
\text { Vitamin A }\end{array}$ & 12 & $26 \%$ \\
\hline Total & 46 & $100 \%$ \\
\hline
\end{tabular}

Berdasarkan tabel di atas pemberian Vitamin A Dosis Tinggi pada Balita dapat disimpulkan bahwa dari 46 Responden, Responden yang diberikan Vitamin A sebanyak 34 Responden (74 \%) dan yang tidak meberikan Vitamin A Dosis Tinggi pada Balita Sebanyak 12 Responden (26\%).

Tabel 3. Distribusi Frekuensi Berdasarkan Tingkat Pengetahuan Ibu di Puskesmas Segiri Samarinda 2018

\begin{tabular}{lcc}
\hline Pengetahuan & Frekuensi & Presentase \\
\hline Baik & 7 & $15,2 \%$ \\
Cukup & 26 & $56,5 \%$ \\
Kurang Baik & 13 & $28,2 \%$ \\
\hline Total & 46 & $100 \%$ \\
\hline
\end{tabular}

Berdasarkan tabel 3. Tingkat Pengetahuan Ibu, dapat disimpulkan bahwa dari 46 Responden, yang memiliki Tingkat Pengetahuan Baik Sebanyak 7 Responden $(15,2 \%)$, yang memiliki Tingkat Pengetahuan Cukup 26 Responden, dan yan memiliki Tingkat Pengetahuan Kurang Baik 13 Responden $(28,2 \%)$.

Analisa Bivariat

Analisa digunakan untuk mengetahui apakah ada hubungan atau pengaruh yang signifikan anatara Pemberian Vitamin A Dosis Tinggi pada Balita dengan Tingkat Pengetahuan Ibu yang dilakukan uji statistik chi square $\left(\mathrm{X}^{2}\right)$ dengan tingkat kepercayaan $95 \%$ dan tingkat kemaknaan apabila $\mathrm{P}$ value $<0,5 \%$ serta derajat kebebasan $(\mathrm{df})=(\mathrm{k}-1)(\mathrm{b}-1)=2$. Untuk melihat hubungan antara variabel bebas dan terikat dapat di lihat tabel sebagai berikut:

Tabel 4. Tabel Silang Responden Berdasarkan Hubungan Antara Tingkat Pengetahuan Ibu dengan Pemberian Dosis Tinggi Pada Balita di Puskesmas Segiri Samarinda 2018

\begin{tabular}{|c|c|c|c|c|c|}
\hline \multirow[t]{5}{*}{ Pengetahuan } & \multirow{2}{*}{\multicolumn{2}{|c|}{$\begin{array}{l}\text { Pemberian Vitamin A } \\
\text { Dosis Tinggi Pada Balita }\end{array}$}} & \multirow[t]{5}{*}{ Total } & \multirow{5}{*}{$\begin{array}{l}\mathrm{X}^{2} \\
\text { Hitung }\end{array}$} & \multirow[t]{5}{*}{$P$ value } \\
\hline & & & & & \\
\hline & Diberikan & Tidak & & & \\
\hline & Vitamin & Diberikan & & & \\
\hline & A & Vitamin A & & & \\
\hline Baik & 6 & 1 & 7 & 7,245 & 0,027 \\
\hline Cukup & 22 & 4 & 26 & & \\
\hline Kurang Baik & 6 & 7 & 13 & & \\
\hline Total & 34 & 12 & 46 & & \\
\hline
\end{tabular}

Berdasarkan tabel 4 diatas dapat dilihat dari 46 Responden, yang mempunyai tingkat kemampuan baik sebanyak 7 Responden, yang memberikan Vitamin A Dosis Tinggi 6 Responden dan 1 Responden tidak memberikan Vitamin A dosis tingggi. Sedangkan yang mempunyai tingkat pengetahuan kurang baik sebanyak 13 Responden yang memberikan Vitamin A Dosis Tinggi sebanyak 6 Responden dan yang tidak memberikan Vitamin A dosis tinggi sebanyak 7 Responden.

Analisa hubungan antara tingkat pengetahuan Ibu dengan Pemberian Vitamin A Dosis Tinggi Menguji Hipotesa menggunakan rumus Chi Square $\left(\mathrm{X}^{2}\right)$ pada 
taraf signifikan $\bar{\alpha} 5 \%$ dan derajat kebebasan $(\mathrm{df})=(\mathrm{k}-1)(\mathrm{b}-1)=2$.

Hasil uji continuity correction diperoleh nilai $\mathrm{P}$ value $=0,027<\bar{\alpha}=0,05$ atau nilai $\mathrm{X}^{2}$ atau nilai $X^{2}$ hitung 7,245\%> $X^{2}$ tabel 5,99. maka dapat disimpilkan bahwa Ho diterima yaitu ada hubungan yang signifikan antara tingkat pengetahuan Ibu dengan pemberian Vitamin A dosis Tinggi pada Balita di Puskesmas Segiri tahun 2018.

\section{PEMBAHASAN}

\section{Pengetahuan}

Berdasarkan Tingkat Pengetahuan Ibu di Puskesmas Segiri Tahun 2018 dapat di simpulkan bahwa dari 46 Responden yang memiliki Tingkat Pengetahuan Baik sebanyak 7 Responden (15,2 \%) dan yang memiliki tingkat pengetahuan yang Kurang Baik sebanyak 13 Responden (28,2 \%). Pengetahuan mempunyai peranan penting dalam menambah wawasan.

Berdasarkan hasil penelitian maka peneliti berpendapat bahwa pengetahuan mempengaruhi pemberian Vitamin A Dosis Tinggi tingkat Pengetahuan Ibu maka daya untuk mengkritis segala sesuatu akan meningkat, semakin luas pengetahuan semakin cakap dalam mengambil keputusan.

\section{Pemberian Vitamin A Dosis Tinggi pada Balita}

Berdasarkan variabel Pemberian Vitamin A Dosis Tinggi pada Balita di Puskesmas Segiri tahun 2018. dapat disimpulan bahwa dari 46 Responden. Responden yang memberikan Vitamin A Dosis Tinggi pada Balita sebanyak 34 Responden (74\%) dan yang tidak memberikan Vitamin A Dosis Tinggi pada Balita sebanyak 12 Responden (26\%).

Dalam program perbaikan gizi sekarang lebih di kenal dengan program bina gizi yang dilaksanakan oleh Departemen Kesehatan setiap 6 bulan yaitu bulan Februari dan Agustus, anak-anak balita di berikan kapsul Vitamin A secara gratis, dengan target pemberian $90 \%$ dari seluruh anak balita dan sisanya $10 \%$ diharaokan pada keluarga yang telah mampu memberikan Vitamin secara mandiri. Kapsul Vitamin A yang di berikan gratis pada balita ini dibedakan atas dua jenis, yaitu :

1. Kapsul Vitamin A Biru dosis 100.000 UI (30.000 ug retinol) hanya diberikan untuk usia 6-11 bulan. Dengan kebutuhan 400 ug perhari maka setiap pemberian akan memenuhi 2-3 bulan ke depan.

2. Kapsul Vitamin A dengan dosis 200.000 UI (60.000 ug retinol) hanya diberikan untuk anak balita dan ibu nifas. Kebutuhan 500 ug perhari maka setiap pemberian memenuhi kebutuhan Vitamin A 5-6 bulan kedepan.

Peneliti berpendapat bahwa penyebab tidak diberikannya Vitamin A Dosis Tinggi Pada Balita dikarenakan kurangnya pengetahuan ibu tentang pentingnya vitamin A. Walaupun tingkat pendidikan ibu kurang baik tetapi ibu tidak bekerja, sehingga seharusnya ibu dapat lebih berkonsentrasi dalam melaksanakan pemberian Vitamin A Dosis Tinggi pada Balitanya.

\section{Hubungan antara Tingkat Pengetahuan Ibu dengan Pemberian Vitamin A Dosis Tinggi pada Balita di Puskesmas Segiri Samarinda Tahun 20121}

Hubungan Antara Tingkat Pengetahuan Ibu dengan Pemberian Vitamin A Dosis Tinggi pada Balita di Puskesmas Segiri Samarinda tahun 2018 dapat dilihat dari 46 Responden dari 7 Responden yang berpengetahuan baik 6 Responden yang memberikan Vitamin A Dosis Tinggi dan 1 Responden tidak memberikan Vitamin A dosis Tinggi. Sedangkan yang mempunyai tingkat pengetahuan kurang baik sebanyak 6 Responden dan yangg tidak memberikan Vitamin A Dosis Tinggi sebanyak 7 Responden.

Pemberian makanan yang mengandung vitamin A dan pemberian kapsul Vitamin A tentunya harus di dukung oleh pengetahuan ibunya tentan manfaat dari pemberian tersebut. Tanpa adanya pengetahuan tentang 
itu, maka mustahil mau memberikan makanan yang mengandung cukup Vitamin A dan membawa anaknya ke Posyandu untuk diberikan kapsul Vitamin, (Nurdin 2012)

Peneliti berpendapat bahwa, Pengetahuan yang baik merupakan keberhasilan hidup, semakin tiinggi tingkat pengetahuan ibu maka daya untuk mengkritis segala sesuatu akan meningkat, makin luas pengetahuan semakin cakap dalam mengambil keputusan. Sehingga kurangnya pengetahuan dan wawasan ibu mempengaruhi pemberian Vitamin A Dosis Tinggi Pada Balita. Walaupun tingkat pendidikan ibu kurang baik tatapi ibu tidak bekerja dan hanya sebagai ibu rumah tangga, seharusnya ibu dapat lebih berkonsentrasi dalam melaksanakan pemberian Vitamin A Dosis Tinggi pada balitanya sesuai dengan hasil analisis menggunakan uji statistic yaitu metode chi square $\left(\mathrm{X}^{2}\right)$ didapatkan hasil Pvalue $0,027 \%<\bar{\alpha} 0,05 \%$ atau $\mathrm{X}^{2}$ hitung 7,245 > X tabel 5,99. Terdapat hubungan antara pengetahuan ibu dengan pemberian vitamin A

\section{KESIMPULAN DAN SARAN}

Berdasarkan hasil penelitian yang dilakukan di Puskesmas Segiri Samarinda tahun 2018, Hasil menunjukkan terdapat hubungan yang signifikan pada taraf antara Tingkat Pengeahuan Ibu dengan pemberian Vitamin A Dosis Tinggi pada Balita di Puskesmas Segiri Samarinda tahun 2018.

\section{DAFTAR PUSTAKA}

Almatsier, S. (2003). Prinsip dasar ilmu gizi. Jakarta: Gramedia Pustaka Utama.

Departemen Kesehatan Republik Indonesia. (2017). Profil Kesehatan Indonesia. Jakarta: Departemen Kesehatan Republik Indonesia.

Dinas Kesehatan Kota Samarinda. (2017). Profil Kesehatan. Samarinda: Dinas Kesehatan Kota Samarinda.

Febry K. D., A. B., \& Marendra, Z. (2010). Smart Parents: Pandai Mengatur Menu \& Tanggap Saat Anak Sakit. Jakarta: GagasMedia.

World Health Organization. (2005). Prevention of Blindness Program. World Health Organization.

Yuliarti. (2016). Hubungan Sikap Ibu dengan Pemberian Vitamin A pada BalitaUsia 12-59 Bulan di Puskesmas Rumbai Pesisir Kota Pekanbaru Tahun 2016. Pekanbaru: AKBID Helvetia. 